\title{
High Risk Factors and Sentinel Lymph Node Biopsy in Cutaneous Squamous Cell Carcinoma: Analysis of Prevalence and Recurrence
}

\author{
Kutanöz Skuamöz Hücreli Karsinomda Yüksek Risk \\ Faktörleri ve Sentinel Lenf Nodu Biopsisi: Rekürrens ve \\ Prevalans Analizi
}

Pembe Oltulu ${ }^{1}$,

Bilsev Ince ${ }^{2}$

Nazlı Turk',

Mehmet Uyar ${ }^{3}$,

Fahriye Kilinc

${ }^{1}$ Necmettin Erbakan University, Meram Faculty of Medicine, Department of Pathology, Konya/Turkey

${ }^{2}$ Necmettin Erbakan University, Meram Faculty of Medicine, Department of Plastic and Reconstructive and Aesthetic Surgery, Konya/Turkey

${ }^{3}$ Necmettin Erbakan University, Meram

Faculty of Medicine, Department of

Department of Public Health, Konya/Turkey

Geliş Tarihi/Received: 07 June 2018

Kabul Tarihi/Accepted: 21 July 2018

\begin{abstract}
Öz
Amaç: Kutanöz skuamöz hücreli karsinomların (KSHK) erken dönemde teşhis edilmesi prognozu etkileyen en önemli faktördür ve iyi prognoza sahip vakalar çoğunluktadır. Yüksek riskli grup olarak tanımlanan bazı vakaların bölgesel tekrarlama ve uzak metastaz oranları oldukça yüksek olup agresif bir seyir izlerler. Son zamanlarda KSHK'larda Sentinel lenf nodu (SLN) örneklemesinin önemini belirlemeye dönük pek çok çalışma yapılmakta ve SLN pozitifliği ile kötü prognoz ilişkilendirilmektedir. Bu çalışmada, KSHK tanısı alan yüksek risk faktörlü vakalarda SLN sonuçlarının prognostik öneminin belirlenmesi amaçlandı. Hastalar ve Yöntem: 2009-2017 yılları arasında KSHK tanısı ile eksizyonel operasyon yapılmış, klinik ve patolojik verileri eksiksiz, çeșitli vücut bölgelerinden toplam 29 hasta çalışmaya dahil edildi. Hastaların yüksek risk faktörleri ve sentinel lenf nodu biopsi sonuçları ile en az 9 aylık klinik takip sonuçları kaydedilerek analiz edildi. AJCC Yüksek risk faktörlerinden en az birine sahip hastalar yüksek riskli grup olarak kabul edildi.

Bulgular: Toplam 29 KSHK hastasının 25 tanesi yüksek risk grubunda idi. Yüksek riskli KSHK hastalarında SLN pozitiflik oranı \%12 ( $\mathrm{n}: 3 / 25)$ olup, düşük riskli 4 hastanın tamamında SLN'ları negatifti. SLN pozitif hastaların tamamına lokal tamamlayıcı lenfadenektomi uygulandı ve hepsi nüks sebebiyle tekrar opere edildi. Yüksek riskli-SLN pozitif KSHK hastalarında nüks oranı \%100 (n:3/3); Yüksek riskli-SLN negatif KSHK hastalarında nüks oranı \%18 (n:4/22) idi. El-ayak lokalizasyonlu hastalarda yüksek nüks oranları (\%41.6) ve SLN pozitifliği belirlendi.

Sonuç: SLN pozitif hastalarda ilerleyen hastalık sürecinde çok büyük oranlarda lokal nüks görülebilmektedir. KSHK'larda el-ayak bölgesi lokalizasyonu; tümörün çapının $0.6 \mathrm{~cm}$ 'in üzerinde olması gerekliliğine bakılmaksızın direkt olarak bir yüksek risk faktörü olabilir.
\end{abstract}

Anahtar Kelimeler: kutanöz, skuamöz hücreli karsinom, sentinel lenf nodu, yüksek risk, rekürrens

\section{Abstract}

Aim: Early diagnosis of cutaneous squamous cell carcinomas (CSCC) is the most important factor affecting prognosis and most patients have a good prognosis. Some patients defined as high-risk group have high rates of regional recurrence and distant metastasis, and follow an aggressive course. In addition, recently numerous studies have being performed for determining the importance of sentinel lymph node sampling, and sentinel lymph node (SLN) positivity has been associated with a poor prognosis. In this study, we aimed to determine prognostic importance of SLN outcomes in patients with high-risk patients diagnosed with CSCC

Patients \& Methods: A total of 29 patients who underwent excisional operation in various body regions with the diagnosis of CSCC between 2009 and 2017, with available complete clinical and pathologic data were included in the study. At least 9-month clinical follow-up results, high risk factors and sentine lymph node biopsy outcomes of the patients were recorded and analyzed. Patients with at least one of the American Joint Committee on Cancer (AJCC) criteria were considered as high-risk group.

Results: Twenty-five of the 29 CSCC patients were in the high-risk group. SLN positivity rate was $12 \%$ ( $n: 3 / 25$ ) in the high-risk CSCC patients, all patients in the low-risk group had negative SLNs. All patients with SLN positive underwent local complementary lymphadenectomy, and all of these patients were reoperated due to recurrence. The rate of recurrence was found as $100 \%(n=3 / 3)$ in high-risk CSCC patients with positive SLN, and $18 \%(n=4 / 22)$ in high-risk CSCC patients with negative SLN. High recurrence rates $(41.6 \%)$ and SLN positivity were observed in patients with hand-foot localizations.

Conclusion: High rates of local recurrence may be seen during progression of the disease in SLN positive patients. Hand-foot localization of CSCCs can be considered as a high risk factor regardless of a tumor diameter should be above $0.6 \mathrm{~cm}$

Key words: Cutaneous, squamous cell carcinoma, sentinel lymph node, high risk, recurrence

\section{INTRODUCTION}

Cutaneous squamous cell carcinomas (CSCC) are malignant tumors that arise from keratinized cells of the epidermis (1). This is the most commonly seen malignancy following basal cell carcinoma among the non-melanoma skin cancers (NMSC) $(80 \%, 20 \%)$
Address correspondence to: Pembe Oltulu, MD Necmettin Erbakan University, Meram Faculty of Medicine Pathology department/Konya/Turkey

e-mail: drpembe@yahoo.com

Cite this article as: Oltulu P, Ince B, Turk N, Uyar M, Kilinc F. High Risk Factors and Sentinel Lymph Node Biopsy in Cutaneous Squamous Cell Carcinoma: Analysis of Prevalence and Recurrence. Selcuk Med J 2018;34(3): 112-118
Disclosure: None of the authors has a financial interest in any of the products, devices, or drugs mentioned in this article. The research was not sponsored by an outside organization. All authors have agreed to allow full access to the primary data and to allow the journal to review the data full access to the primary data and to allow the journal to review the data if requested. 
(2). Its incidence may vary according to geographic regions (2-4).

Early diagnosis of CSCC is the most important factor affecting prognosis and most patients have a good prognosis (5). Some patients defined as highrisk group have high rates of regional recurrence and distant metastasis, and follow an aggressive course. These cases are defined as high-risk group (2,4-6). According to the American Joint Committee on Cancer (AJCC) reports, the most important high risk factors include diameter, depth, localization, and differentiation degree of the tumor, and the presence of perineural invasion (Table 1). Recently, lymph node involvement also presents as an indicator for determination of high-risk group in CSCCs just like malignant melanomas $(2,4-7)$.

The lymph node in the body region to which a malignant tumor first drains is named as sentinel lymph node (SLN). This is the first lymphoid target where tumors reach for the first time via lymphatic route $(4,7-$ 13). The importance of SLN sampling in identification of the occult lymph node metastases has been established, and accepted as a prognostic factor (14). There are quite variable rates in the literature related to SLN invasion, mean rate of positivity has been reported between $7.9 \%$ and $14.6 \%$ in some current recent reviews and meta-analyses $(7,10-13)$. It has been proposed that patients with metastasis detected in SLN have a worse prognosis and a lower lifetime $(2,4,5)$. In these studies underlining the importance of SLN sampling in the staging and prognosis of CSCCs, it has been stated that further studies to be performed in optimal conditions are needed about addition of the SLN positivity criterion in the staging guidelines $(2,5,10)$.

In this study, we aimed to determine prognostic

Table 1. High risk factors accordig to AJCC reports $(2,12)$

\section{High-risk features in Cutanous Squamous Cell Carcinoma*}

Tumor size: $\geq 2 \mathrm{~cm}$

Tumor diferantiation: Poorly differentiated

$$
\text { or } \geq \text { Grade } 3
$$

Tumor depth: $\geq 2 \mathrm{~mm}$ or $\geq 0.2 \mathrm{~cm}$

Perineural invasion: +

Anatomic site: Ear or lip importance of SLN outcomes in patients with highrisk patients diagnosed with CSCC.

\section{PATIENTS AND METHODS}

A total of 38 patients who underwent excisional operation in our hospital due to CSCC between 2009 and 2017 were retrospectively screened. Whereas patients with SLN sampling carried out, having complete clinical data, and all preparations and tumor blocks available in the pathology archive were included in the study; patients with missing clinical and pathologic data, and those without a clear diagnosis of CSCC were excluded from the study. One patient diagnosed with keratoacanthoma, 2 patients with meta typical carcinoma, and 1 patient with sebaceous carcinoma following the excision, and 5 patients due to missing clinical or pathologic data were excluded. Local recurrence and metastasis status of the patients after at least 9 months of follow-up was recorded. Patients followed-up shorter than 9 months were not included in the study.

\section{Histopathological Evaluation:}

Hematoxylin \& Eosin (H\&E) stained preparations of SLN and cutaneous tumor resections of the patients were obtained from the pathology archive. Appropriate slides were selected for the microscopic examination. Lymph node preparation were evaluated for metastasis, and preparations of the main tumors for high risk criteria under a light microscope (olympus BX51). In the histopathologic evaluation; localization, diameter, depth, and differentiation degree of the tumor, and presence of perineural invasion that were accepted as the high risk factors by $\operatorname{AJCC}(2,12)$ were studied and recorded.

Perineural invasion was evaluated with yes/ no, differentiation degree with good/moderate/poor (Grade 1-3; Figure 1), tumor depth with Clark level (Levels 1-5) system or Breslow depth measurement system ( $\mathrm{mm}$ or $\mathrm{cm}$ ).

Patients' age, gender, localization, high risk criteria, SLN positivity status (Figure 2), tumor recurrence and/or metastasis status, lifetime from the diagnosis, and distance of the closest surgical margins were recorded and statistically analyzed. Correlation of SLN positive/negative status with high risk criteria and recurrence was proportionately evaluated; since the number of SLN positive cases was not sufficient, a comparative analysis in terms of prognostic factors could not be performed with SLN negative cases.

\section{Statistical analysis:}

Statistical analysis was performed using SPSS 


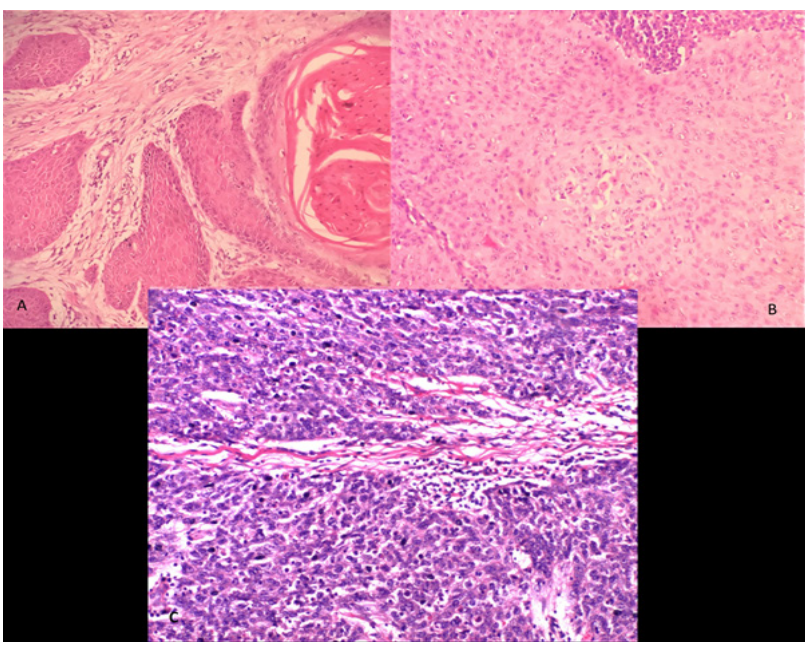

Figure 1. H\&E; A) X20 B,C) X40; Histopathological features of Cutaneous squamous cell carcinoma according to differantiation; Grade 1 (A), Grade 2 (B), Grade 3 (C)

24. 0 (IBM, Armonk, NY, USA) software. Descriptive statistics are expressed as number and percentages. The results were shown with Tables and Charts.

\section{RESULTS}

A total of 29 (19 males, 10 females) patients were included in the study. The mean age of diagnosis was $66.9 \pm 12.4$ (range: 44-90) years. The lesions were from nine different body regions. The lesions were most commonly localized in hands (8 patients), followed by lower lip (7 patients) (Table 2).

Evaluating the patients for high risk factors according to AJCC criteria; 4 patients were in the low-risk group and 25 patients in the high-risk group. When patients in the high-risk group were analyzed; 9 patients (36\%) had only one of the risk factor, 13 patients $(52 \%)$ had any two of the risk factors, 1 patients $(4 \%)$ had any three of the risk factors, and 2 patients (8\%) had any four of the risk factors, while there was no any patient who had all risk factors together. Most of the high-risk patients had 2 risk factors ( $\mathrm{n}: 13,52 \%)$. Distribution of the high risk factors in all patients and the patients with positive and negative SLN is shown in Table 3.

Among all patients, SLN biopsy was positive in only $3(10.3 \%, n=3 / 29)$ patients, and all the patients with positivity were in the high-risk group and had extremity localization (leg in 2 patients and hand in 1 patient). SLN positivity rate was found as $12 \%$ (n: $3 / 25$ ) among the high risk CSCC patients. Whereas 2 patients with SLN positive had 3 high risk factors, one patient had 2 high risk factors. All patients

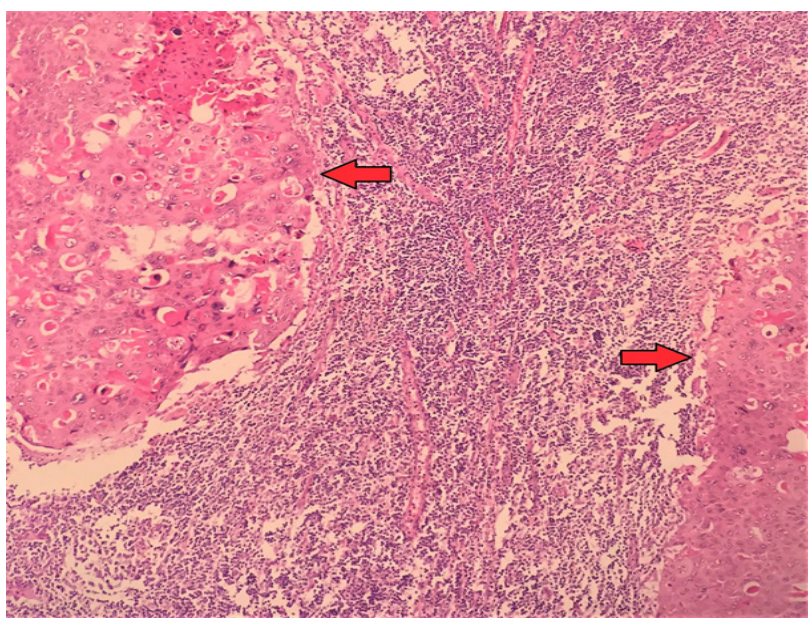

Figure 2. H\&E, Metastatic tumoral islands (red arrow) of cut aneous squamous cell carcinoma in a sentinel lymph node biopsy

with SLN positive underwent local complementary lymphadenectomy, and all three patients were reoperated due to recurrence.

Immediately after the diagnosis, local complementary lymphadenectomy was performed in $10(34.5 \%)$ patients (3 SLN+, 7 SLN-). Positivity was not observed in any patient in the complementary lymphadenectomies. The mean postdiagnosis disease duration in all patients was $38.1 \pm 24.1$ months (9-108 months), and 9 patients (31\%) were reoperated due to recurrence. None of the patients died from the disease. Of the patients who developed recurrence, 2 were in the low-risk group and 7 in the high-risk group. Distance of the closest surgical margin was $0.3 \mathrm{~cm}$ in 2 patients with recurrence, and at least $0.5 \mathrm{~cm}$ in the remaining 7 patients.

In the present study, there were only 4 patients in the low-risk group, with $2(50 \%, \mathrm{n}: 2 / 4)$ of them

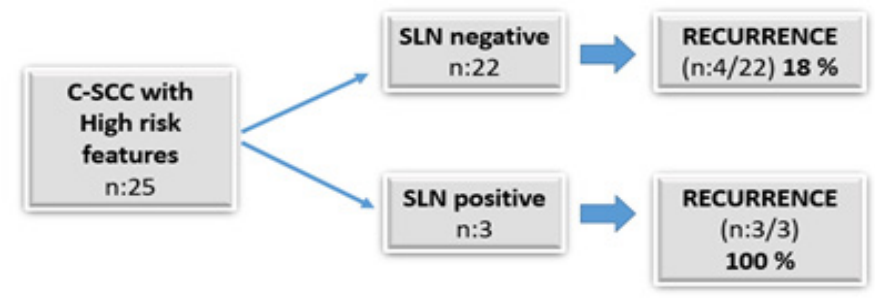

Figure 3. The rates of SLN positivity and recurrences in current in study 
Table 2. The Data distribution of all cases, PNI: Perineural invasion; LVI: Lymphovascular invasion, M:male, F: Female

\begin{tabular}{|c|c|c|c|c|c|c|c|c|c|c|c|c|c|c|c|}
\hline 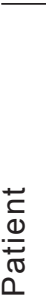 & ஹ্ঠু & $\begin{array}{l}\frac{1}{0} \\
\frac{0}{0} \\
\frac{1}{0} \\
0\end{array}$ & 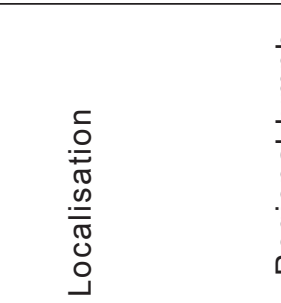 & 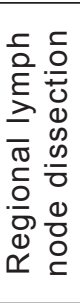 & 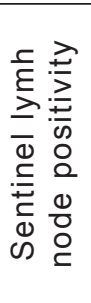 & 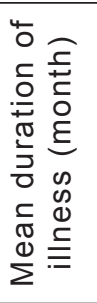 & 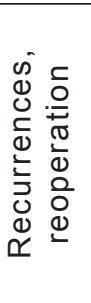 & $\begin{array}{l}\widehat{E} \\
\frac{\tilde{U}}{0} \\
\frac{\mathbb{N}}{\omega}\end{array}$ & 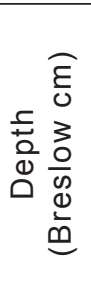 & $\begin{array}{l}\overline{0} \\
\frac{0}{0} \\
\frac{x}{\frac{\sigma}{\sigma}} \\
\frac{0}{U}\end{array}$ & 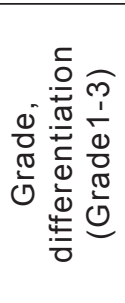 & 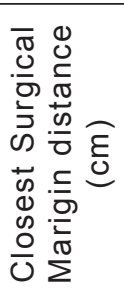 & $\sum_{\square}^{*}$ & $\stackrel{*}{>}$ & 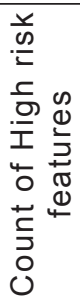 \\
\hline 1 & 78 & $M^{*}$ & Lower Lip & - & - & 19 & - & 1,2 & 0.6 & 4 & 2 & 0,5 & - & 0 & 2 \\
\hline 2 & 68 & $F^{*}$ & Nose & - & - & 18 & - & 3,5 & 0.6 & 4 & 1 & 0,4 & - & 0 & 2 \\
\hline 3 & 50 & M & Lower Lip & - & - & 61 & - & 0,8 & 0.3 & 4 & 1 & 0,6 & - & 0 & 2 \\
\hline 4 & 77 & $M$ & Right Hip & - & - & 27 & - & 1,9 & 0.4 & 4 & 3 & 1 & - & 0 & 2 \\
\hline 5 & 44 & $M$ & Body & - & - & 28 & - & 2,2 & 0.9 & 5 & 1 & 1,2 & - & 0 & 2 \\
\hline 6 & 49 & $M$ & Right Hand & - & - & 57 & - & 1,1 & 0,4 & 4 & 1 & 0,6 & - & 0 & 1 \\
\hline 7 & 59 & $M$ & Right Foot & + & - & 37 & + & 10 & 1,1 & 5 & 1 & 0,9 & - & 0 & 1 \\
\hline 8 & 66 & $M$ & Right Foot & + & - & 32 & + & 1,6 & 0,3 & 2 & 1 & 0,9 & - & 0 & 1 \\
\hline 9 & 52 & M & Right Leg & + & + & 33 & + & 5,4 & 0,9 & 5 & 1 & 0,6 & - & 0 & 2 \\
\hline 10 & 77 & $M$ & Face & - & - & 34 & - & 2 & 0,4 & 3 & 1 & 0,3 & - & 0 & 2 \\
\hline 11 & 79 & $\mathrm{~F}$ & Right Hand & - & - & 32 & - & 0,9 & 0,18 & 3 & 1 & 0,5 & - & 0 & 0 \\
\hline 12 & 77 & $\mathrm{~F}$ & Right Foot & + & - & 32 & + & 0,4 & 0,19 & 2 & 1 & 1,4 & - & 0 & 0 \\
\hline 13 & 59 & $M$ & Lower Lip & - & - & 37 & - & 2 & 1,1 & 5 & 1 & 0,3 & + & 0 & 4 \\
\hline 14 & 84 & $M$ & Lower Lip & - & - & 38 & - & 3 & 0,8 & 4 & 1 & 0,6 & + & 0 & 4 \\
\hline 15 & 47 & $M$ & Left Hand & - & - & 40 & + & 0,9 & 0,18 & 2 & 1 & 0,5 & - & 0 & 0 \\
\hline 16 & 51 & $M$ & Lower Lip & - & - & 50 & - & 0,9 & 0,17 & 2 & 2 & 0,8 & - & 0 & 1 \\
\hline 17 & 59 & $M$ & Right Hand & - & - & 62 & - & 3,2 & 0,4 & 4 & 1 & 0,3 & - & 0 & 2 \\
\hline 18 & 57 & $M$ & Lower Lip & - & - & 64 & - & 1,4 & 0,6 & 4 & 1 & 0,6 & - & 0 & 2 \\
\hline 19 & 65 & $M$ & Lower Lip & - & - & 108 & + & 0,8 & 0,1 & 1 & 1 & 0,5 & - & 0 & 1 \\
\hline 20 & 66 & $\mathrm{~F}$ & Right Hand & - & - & 70 & - & 1,2 & 0,6 & 5 & 1 & 0,9 & - & 0 & 1 \\
\hline 21 & 70 & $\mathrm{~F}$ & Right Hand & - & - & 73 & - & 1 & 0,4 & 3 & 1 & 0,5 & - & 0 & 1 \\
\hline 22 & 80 & $\mathrm{~F}$ & Right Hand & - & - & 69 & - & 0,8 & 0,3 & 2 & 1 & 0,6 & - & 0 & 1 \\
\hline 23 & 78 & $M$ & Lower Lip & - & - & 19 & - & 1,2 & 0,4 & 3 & 2 & 0,4 & - & 0 & 2 \\
\hline 24 & 67 & $\mathrm{~F}$ & Right Hand & + & - & 18 & - & 4,2 & 0,3 & 4 & 2 & 0,5 & - & 0 & 2 \\
\hline 25 & 63 & $\mathrm{~F}$ & Left Leg & + & - & 11 & - & 1,6 & 0,3 & 3 & 2 & 0,6 & - & 0 & 1 \\
\hline 26 & 76 & $\mathrm{~F}$ & Left Leg & + & + & 9 & + & 2,5 & 1,4 & 4 & 1 & 1,3 & + & 0 & 3 \\
\hline 27 & 80 & $M$ & Right Hand & + & + & 9 & + & 1,4 & 1,8 & 5 & 3 & 0,3 & + & 0 & 2 \\
\hline 28 & 73 & $M$ & Right temporale & + & - & 10 & - & 0,5 & 0,1 & 2 & 1 & 1 & - & 0 & 0 \\
\hline 29 & 90 & $\mathrm{~F}$ & Face & + & - & 9 & + & 4,4 & 1,8 & 5 & 2 & 0,3 & + & 0 & 2 \\
\hline
\end{tabular}

developed recurrence after the diagnosis. The localization was on the hand in one of the patients with recurrence in the low-risk group, and on the foot in the other patient, and both had no SLN positivity ( $n: 0 / 2)$. Seven patients $(28 \%, n: 7 / 25)$ in the high-risk group developed recurrence, and 3 patients $(12 \%$, $\mathrm{n}: 3 / 25)$ had positive SLN. Among the patients in the high-risk group, the rate of recurrence was 100\% $(n: 3)$ in the patients with positive SLN, and 9\% (2/22) in the patients with negative SLN (Graphic).

When localizations were evaluated; hand-foot $(41.4 \%, n: 12 / 29)$ and lower lip (24.1\%, n:7/29) were the most common localizations. Whereas only one patient $(14.3 \%)$ with lower lip localization developed recurrence, No SLN positivity was observed with this localization. Five patients $(41.6 \%)$ with hand-foot localization developed recurrence with SLN positivity was found in one $(8.3 \%)$ patient. One patient with recurrence in this localization had clear surgical margins, and was in the low-risk group.

\section{DISCUSSION}

Although most patients diagnosed with CSCC have a good prognosis, a few cases in the high-risk group with the criteria of poor diagnosis have an aggressive clinical course and higher rates of local recurrence and metastasis (5,9-12). Risk factors defined by AJCC are shown in Table 2. Determination of tumor diameter based on body regions are among the risk factors in the guidelines by NCCN (National Comprehensive Cancer Network). Patients with a diameter $>2 \mathrm{~cm}$ in the trunk and extremities; $>1 \mathrm{~cm}$ in the cheeks, forehead, skul skin and neck; and $>0.6 \mathrm{~cm}$ in the face, genitalia, hands and feet are included into high- 
Table 3. Distribution of high-risk factors according to Sentinel Lymph Node (SLN *) status in all cases, PNI: Perineural invasion

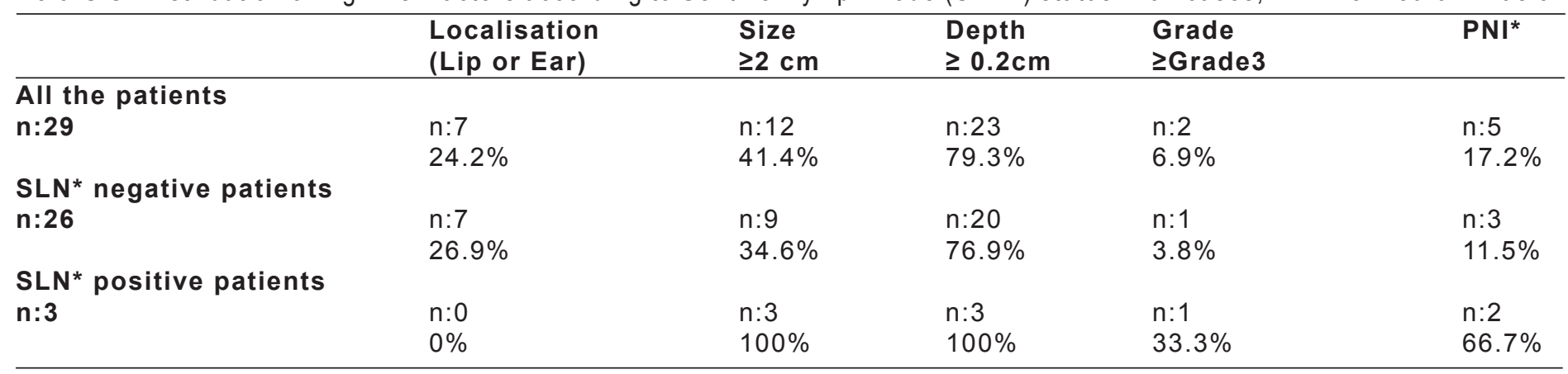

risk group (9-13). In our study, an aggressive course and positive SLN were found in 2 patients (50\%) with leg localized lesions among the 4 patients with extremity localized tumors of $>2 \mathrm{~cm}$ diameter (Table 1). No recurrence was observed in the 2 patients with tumors of $<2$ diameter, consistently with the literature. In our study, all three patients with facial localization had a tumor diameter $>0.6 \mathrm{~cm}$, and none of them had recurrence or SLN positivity, while patients with hand-foot localization had a tumor diameter $>0.6 \mathrm{~cm}$, with a recurrence rate of $41.6 \%$ and SLN positivity of $8.3 \%$. The rate of recurrence was lower $(14.3 \%)$ in the lip area which was directly included in the high-risk criteria regardless the diameter compared to handfoot localization, and SLN positivity was not observed in this localization. Disease duration of 108 weeks in a patient re-operated due to recurrence of the lower lip region was an indicator of good prognosis. An important point to be noted in our study was that the presence of PNI (n:2) was detected in all CSCC patients with a diameter $>2 \mathrm{~cm}$. Another remarkable point was that the rate of recurrence was $11 \%$ (n:1/9) in lower lip localization, while this rate was 55\% (n:5/9) in hand-foot localization. Patients with recurrent hand-foot localization had clear surgical margins except for one patient. Lip localization is defined as a direct risk factor in ASCC. In our study, high rates of recurrence and SLN positivity in patients with handfoot localization, and one patient with recurrence of this region being in the low-risk group, suggest that hand-foot localization may be a diameter independent high risk factor just as lip and ear localizations. As specified in a study by Oltulu et al., poor prognosis in hand-foot region may be resulted from hand-foot dermis thickness thinner than that of the other regions $(15,16)$. Further optimized and controlled studies with large series are needed to determine whether this region should be directly included in the high-risk group.

In the present study; body region independent diameter, PNI and tumor depth were higher in patients with recurrence, consistently with the literature $(55 \%$, $33 \%$, and $77 \%$; respectively). When the differentiation was assessed; poor differentiation of grade 3 was observed only in two patients with one of them developed recurrence. Most patients with recurrence had grade 1 differentiation ( $\mathrm{n}: 7 / 9 ; 77.7 \%$ ). However, evaluating the rates among the 29 patients, rate of recurrence was found as $33 \%$ in grade 1 patients, $16 \%$ in grade 2 patients, and $50 \%$ in grade 3 patients, consistently with the literature.

A study by Clayman et al. (17), demonstrated presence of the high rates of perineural invasion and subcutaneous invasion especially in high-risk CSCC patients with a tumor diameter $>4 \mathrm{~cm}$. In our study there were three patients with a diameter $>4 \mathrm{~cm}$, with PNI observed in one patient (33.3\%), subcutaneous invasion was found in all of them $(100 \%)$ as in the study by Clayman et al. Because this data may be a precursor of a high subcutaneous invasion during total excision of the tumor, especially when tumors of a diameter $>4 \mathrm{~cm}$ are excised, it may provide convenience to the surgeon in planning of base surgical margin measurement.

There are numerous studies in the literature which published worse results of the patients having high risk criteria (2,9-12), and the rates of local recurrence and metastasis are reported between $10 \%$ and $47 \%$ (10). In our study, recurrence rate in the patients with at least one of the high-risk criteria was compatible with the literature (n:7/25, 28\%). Since our number of low-risk patients was quite low, the two groups could not be compared statistically.

SLN evaluation is an important prognostic criteria which has been involved in routine use, and studies and meta-analyses have proposed that the development 
of lymph node metastasis is an important marker also in CSCCs as in melanoma among skin cancers $(2,5,9-14,17-19)$. It has been reported that CSCC is one of the few malignant skin tumors that have the potential of causing metastasis to the regional lymph nodes with quite variable rates of SLN positivity in high-risk patients $(2,7,10-13,18)$. In two studies with 6 and 51 cases, no positive lymph node was observed in high-risk CSCC $(4,5)$, while rate of positivity have been reported between $11-44 \%$ in systematic reviews, meta-analyses, and independent trials (2,913). The number of patients was less than 50 in most of the studies $(2,4-6,9-13,18)$. Positivity was found as $44 \%$ in a series of 9 patients, and $14 \%$ in a large series including CSCCs (9). Number of the patients in studies from the literature varied between 6 and 57 (9), our number of patients (total: 29; high-risk group: 25) was similar with the studies in the literature. The rates of SLN positivity were reported as $7.9 \%, 12 \%$, $14.6 \%$ and $12.3 \%$ in high-risk CSCC patients in the literature screening and meta-analyses including 566, 324, 260 and 130 patients; respectively $(2,9,11,13)$. In our series, positivity rate was $12 \%$, and despite the low number of our patients this rate was consistent with the literature.

Whereas high-risk CSCC patients have good healing and survival rates with an adequate excision, 5-year survival was observed to fall in metastatic patients $(9,10)$. In a few studies with development of regional lymph node metastasis in the literature, rates of the local recurrence and distant metastasis were found to be increased $(5,9)$. However, there were no prospective controlled studies that have carried out 5-year survival risk analysis, and determined its prognostic importance in patients with positive SLN $(2,5,9,11)$. In a study with 26 cases, 3-year survival rates were reported as $100 \%$ in SLN negative patients, and $20.8 \%$ in SLN positive patients (20). In a series by Reshly et al. in 2003, 2-year survival rate was reported as $50 \%$ in SLN positive patients (10). In the present study, mean follow-up duration was found as $40.1 \pm 25.2$ months in high-risk group. Among the high-risk patients, 7 patients had a followup $>5$ years, and 9 patients $>4$ years, and all these patients survived. Of total 9 patients with recurrence, one patient had a follow-up duration $>5$ years, 6 patients $>32$ months, and no death occurred. None of the follow-up durations were longer than 3 years in SLN positive patients (Table 2).

Although lack of 5-year survival information is the most important limitation of our study, no other studies were found to clearly report 5-year survival information in the literature screening. Another limitation of this study is non-homogenous distribution and insufficient number of groups and data. Looking to the literature, it was found that the other studies showed similarities to our study, and no any study was found with sufficient number of cases and homogeneous distribution of the groups according to regions and risk factors. When national studies were screened, we found a case report of 2 patients with vulvar SCC and a series of 30 cases evaluating SLN biopsy in skin tumors $(8,21)$. Only 6 of 30 patients had CSCC, with SLN positivity was reported in one (16.6\%) of them. In that study, there was no any information about local recurrence or survival (8). Despite all limitations, recurrence rate was $100 \%$ in high-risk patients with positive SLN, and $18 \%$ in high-risk patients with negative SLN (Figure 3 ), with a significant difference between them. Being one of the few studies with large series conducted on this issue in our country, and thinking that some results would provide contribution to the international literature make the present study valuable.

In conclusion;

- High rates of local recurrence may be seen in progressing disease course in SLN positive patients. Further studies to report 5-year survival outcomes in CSCC patients who underwent SLN investigation and to determine the net risk-survival analysis could provide clear data on the association of SLN positivity with survival and its prognostic importance in addition the association between SLN positivity and rate of recurrence.

- High rates of recurrence and SLN positivity seen in patients with hand-foot localization, suggest that these two regions can be added to ear and lip regions that were reported as high-risk regions in AJCC reports, independently from the diameter. Further prospective controlled studies with larger series are warranted on hand-foot CSCC.

Conflict of interest: Authors declare that there is no conflict of interest between the authors of the article.

Financial conflict of interest: Authors declare that they did not receive any financial support in this study.

Address correspondence to: Pembe Oltulu, MD

Necmettin Erbakan University, Meram Faculty of Medicine Pathology department/Konya/Turkey

Mail:drpembe@yahoo.com

Twitter: @pembeoltulu

TIf: 05059584808 


\section{REFERENCES}

1. Motley R, Kersey P, Lawrence C. Multiprofessional guidelines for the management of the patient with primary cutaneous squamous cell carcinoma. Br J Dermatol 2002;146(1):18-25.

2. Schmitt AR, Brewer JD, Bordeaux JS, et al. Staging for cutaneous squamous cell carcinoma as a predictor of sentinel lymph node biopsy results: Meta-analysis of American Joint Committee on cancer criteria and a proposed alternative system. JAMA Dermatol 2014;150(1):19-24.

3. Diepgen TL, Mahler $\mathrm{V}$. The epidemiology of skin cancer. Br J Dermatol 2002;146 Suppl 61:1-6.

4. Samsanavičius D, Kaikaris V, Norvydas SJ, et al. Sentinel lymph node biopsy for high-risk cutaneous squamous cell carcinoma: Analysis of recurrence-free survival. Medicina (Kaunas) 2016;52(5):276-82.

5. Kwon S, Dong ZM, Wu PC. Sentinel lymph node biopsy for high-risk cutaneous squamous cell carcinoma: Clinical experience and review of literature. World J Surg Oncol 2011;9(80):1-7.

6. Antonio JK, Santini S, Politi D, et al. Sentinel lymph node biopsy in squamous cell carcinoma of the head and neck: 10 years of experience. Acta Otorhinolaryngol Ital 2012;32(1):1825.

7. Fahradyan A, Howell AC, Wolfswinkel EM, et al. Updates on the management of non-melanoma skin cancer (NMSC). Healthcare (Basel) 2017;5(4): E82.

8. Şirvan SS, Akgün I, Sevim KZ, et al. Deri tümörlerinde sentinel lenf bezi biyopsisinin kullanımı. ŞEEAH Tıp Bülteni 2016;50(3):220-7.

9. Ahadiat $O$, Higgins $S$, Sutton $A$, et al. SLNB in cutaneous SCC: A review of the current state of literature and the direction for the future. J Surg Oncol 2017;116(3):344-50.

10. Reschly MJ, Messina JL, Zaulyanov LL, et al. Utility of sentinel lymphadenectomy in the management of patients with high-risk cutaneous squamous cell carcinoma. Dermatol Surg 2003;29(2):135-40.

11. Tejera-Vaquerizo A, García-Doval I, Llombart B, et al. Systematic review of the prevalence of nodal metastases and the prognostic utility of sentinel lymph node biopsy in cutaneous squamous cell carcinoma. J Dermatol 201827. doi: 10.1111/1346-8138.14342. [Epub ahead of print]
12. Lydiatt WM, Patel SG, O'Sullivan B, et al. Head and neck cancers-major changes in the American Joint Committee on cancer eighth edition cancer staging manual. CA Cancer J Clin 2017;67(2):122-37.

13. Lhote R1, Lambert J, Lejeune J, et al. Sentinel lymph node biopsy in cutaneous squamous cell carcinoma series of 37 cases and systematic review of the literature. Acta Derm Venereol 2018 Apr 12. doi: 10.2340/00015555-2942. [Epub ahead of print]

14. Kanyilmaz G, Aktan M, Yavuz BB, et al. Five-year survival outcomes of breast cancer and prognostic factors. A single institution experience. Selcuk Med J 2017;33(1): 5-9.

15. Oltulu P, Ince B, Kokbudak N, et al. Measurement of epidermis, dermis, and total skin thicknesses from six different body regions with a new ethical histometric technique. Turk J Plast Surg 2018;26:56-61.

16. Chopra K, Calva D, Sosin M, et al. A comprehensive examination of topographic thickness of skin in the human face. Aesthet Surg J 2015;35(8):1007-13.

17. Clayman GL, Lee JJ, Holsinger FC, et al. Mortality risk from squamous cell skin cancer. J Clin Oncol 2005;23(4):759-65.

18. Brantsch KD, Meisner C, Schon sch B, et al. Analysis of risk factors determining prognosis of cutaneous squamous-cell carcinoma: A prospective study. Lancet Oncol 2008;9: 71320.

19. Rowe DE, Carroll RJ, Day CL. Prognostic factors for local recurrence, metastasis, and survival rates in squamous cell carcinoma of the skin, ear, and lip. Implications for treatment modality selection. J Am Acad Dermatol 1992;26: 976-90.

20. Takahashi A, Imafuku S, Nakayama J, et al. Sentinel node biopsy for high-risk cutaneous squamous cell carcinoma. Eur J Surg Oncol 2014; 40(10):1256-62.

21. Gültekin Ö, Göl M, Saygılı U, et al. Vulvanın skuamöz hücreli karsinomunda sentinel nod incelemesi: İki olgu sunumu. Turkiye Klinikleri J Gynecol Obst 2005;15(2):98-102. 